\title{
Product-Service Lifecycle Management in Manufacturing: An Industrial Case Study
}

\author{
Margherita Peruzzini, Michele Germani, and Eugenia Marilungo \\ Università Politecnica delle Marche, via Brecce Bianche 12, 60131 Ancona, Italy \\ \{m.peruzzini,m.germani, e.marilungo\}@univpm.it
}

\begin{abstract}
Product-Service is a recent concept based on a novel product understanding consisting of integrated product and service shares. It represents a new trend for industries to innovate their artefacts and create fresh business opportunities. However, moving from product to services requires the identification of the needed assets to create the new solution and the integration of both productrelated and service-related activities into a unique product-service lifecycle. In practice, such an evolution can be defined theoretically but it is hard to implement since supporting tools are strongly product-centred yet. As a consequence, product-service is still a fascinating idea especially in manufacturing sector. This paper tells about a success story of product-service management in manufacturing industry; it describes how a household appliances' manufacturer shifted from traditional product lifecycle towards product-service lifecycle to manage the new service. The study starts from analysis of the AS-IS processes and mapping of the ecosystem tangible and intangible assets, and describes how the company was supported into the definition of an integrated product-service lifecycle.
\end{abstract}

Keywords: Product Lifecycle Management, PSS (Product-Service System), PLM improvement concept, Collaboration, Virtual Enterprise.

\section{Introduction}

Numerous manufacturing enterprises are challenged by the transition from a traditional product-oriented model to a new extended service-oriented one, which can be realized by Product-Service Systems (PSS) [1]. This trend mainly consists of adding a wide range of services to increase the value perceived by the customers and better satisfy their needs. In particular, Product-Service Systems (PSSs) consist of the combination of tangible and intangible assets and their integration in Product-Service modules, which are mutually determinant throughout the whole lifecycle [2]. Additional services and added value move the product towards an extended product really tackling the customer's needs and offering a solution. In this context, technical services represent the easiest way to create a PSS in manufacturing industry: from maintenance to training, retrofitting and product monitoring. Indeed, they can be easily realized by improving the product communication capabilities in order to make data flow from product to external systems to realize supporting or differentiating services. This integrated understanding leads to new and customer-oriented solutions, and 
enable innovative functions and result-oriented business models. Furthermore, services can bring great advantages for industry: from the economical viewpoint, services can create higher profit margins and contribute to higher productivity by means of reduced investment costs along the lifetime as well as reduced operating costs for the final users [3]; from an ecological viewpoint, product-services can be more efficient thanks to a more conscious product usage, an increased resource productivity and a close loop-chain manufacturing as reported by some examples [4]; finally, services create socially advanced scenarios, as they secure knowledge intensive jobs and contribute to a more geographically balanced wellbeing distribution [5].

However, producing product-services opens a big issue in enterprise modelling and data management since they overcome the model of traditional products and the boundaries of the single company. Indeed, if tangible assets can found in the manufacturer company and its supply chain, intangible assets require medium-term collaboration with service companies and the creation of the so-called Virtual Ecosystems [6]. These ecosystems are replacing the former single enterprise and take over the lifetime responsibilities for the new PSS; they were also called Virtual Manufacturing Enterprise (VME). As a result, the cohesion between the product, associated services and the life cycle ideas is expressed by the product-service concept. For this reason, product-service requires the management of all assets and entities involved as well as the PSS designed and by modelling the complex the interrelations between products and non-physical services. In this context, the paper describes an industrial case study focusing on product-services in household appliances sector.

\section{Product-Service Management for Manufacturing Companies}

A product-service consists of proposing a mix of tangible products and intangible services designed and combined to optimize the product use and increase the value for customers [7]. Value creation can be provided through an extended business network involving different stakeholders, which concur to create the services. Product-service idea starts from the concept of extended product [2], where intangible services are incorporated into a core product to add value. The term PSS usually includes the tangible product, the related services, the enterprise network and the infrastructures needed [8]. In manufacturing applications PSS are almost based on technical services for two main reasons: they have a concurrent lifetime to the product to which they relate since they support the product use and interact with the customers during the operation stage [9]; and they can be added to product with low impact for manufacturers since they are usually available at low-cost and have a shorter time-to-market [10]. After-sales services are usually provided as PSS. Here are located the services that ensure and restore the availability of the material good. Furthermore, they can extend the life cycle of the product and reduce consumption, emissions and operating costs [11]. Specifically, after-sales services encompass: maintenance, hotline services, tele-service, spare parts, service and customer training.

There are various forms of servitization with different features and, as suggested by [12], there is a transition line from pure product manufacturers to service 
providers. At one extreme of the line there are product manufacturers, which produce core products and services purely as an add-on to the product, and services are used as a differentiating factor in product marketing strategy. At the other extreme, there are service providers, whose products are merely an add-on to services since products represent only a small part of total value creation. The transition is based on an extended service business, starting with a few product-related services and ending up with a large number of service offerings. In the evolution of servitization, many manufacturing companies have moved into services and that caused the boundaries between products and services to become blurred [13].

In parallel with servitization, industrial models in manufacturing have recently evolved from rigid, deterministic supply chains, to a next generation of completely flexible, open and dynamic ecosystems with new economic opportunities. In such ecosystems, members share knowledge, innovate and collaborate together, interact or connect with each other, design new products, communicate globally and develop projects [14]. Ad-hoc selection of the most suitable partners for each customer demand is needed in order to become more flexible and reactive on the global dynamic marketplace [15]. In fact, the collaboration between the main manufacturing company and its key partners is fundamental to propose a new value by the right delivery channels and the best strategies by developing new business models.

It is evident that the increasing importance of services represents big challenges for manufacturing companies. However, the biggest challenge is carrying out a reliable management of PSS and a successful coordination of all the activities related. In particular, small and medium businesses often do not have sufficient knowledge and resources to professionalise its service business.

Manufacturing companies have usually a clearly defined product development process, but they lack a sufficiently defined service development process as found in traditional service companies. Many companies recognise that the existing corporate structures and processes do not allow for efficient development and market positioning of innovative services. In addition, they are faced with the problem of being poorly equipped with appropriate approaches, methodologies and tools for an efficient development of services. In addition, due to the often unclear or unstructured portfolio of services in the firms, a lot of time and resources is spent for coordination and consultation work between the main actors.

In a nutshell, services represent an excellent opportunity for manufacturing companies, but companies need to be supported properly to fully catch this new opportunity. Several methods have been recently proposed to manage PSS (from modularization-focused approach, to stochastic and behaviour-focused approach, until lifecycle-focused methods) [16]. However, some of them are very theoretical and hard to implement in practice, while others are too specific and have a limited applicability. Several recent studies focused on requirement elicitation in product-services [17-18]: they highlights the main challenges of requirement engineering in virtual manufacturing ecosystems and proposes an approach based on Business Use Cases (BUC) and Serious Games to elicit PSS requirements and investigate the PSS lifecycle. Moreover, the existing business models in manufacturing are not well suited to servitization and collaboration, which are required to enter new markets [19]. Indeed the company 
business model must change from product to services: PSS requirements should be satisfied through the analysis of both internal and external factors (i.e. environmental, economic, social, technological and political), and the ecosystem factors. In this context, STEEP analysis well support the identification of internal (related the company structure) and external (related the company ecosystem) requirements and the definition of a new business model for a certain idea. Then, Canvas Business Model can straightforwardly schematize the model by providing a clear definition of how an organization creates, delivers, and captures value throughout its ecosystem [20].

However, companies still have a lot of difficulties in selecting the most appropriate tools for supporting PSS and selecting the partners to create the Virtual Manufacturing Enterprise (VME), as well as to define a valuable business model and a simple but reliable PSS lifecycle to refer their activities and those of their partners in the VME.

\section{Methodology to Shift from Product to Product-Service Lifecycle Management}

The research methodology provides a set of tools and a straightforward workflow to support manufacturing companies in realizing and managing a product-service idea to innovate their business. The crucial point is the analysis of the company ecosystem and the correlation between the tangible and intangible assets offered and the assets necessary for the new PSS, and the definition of a valuable PSS business model.

The proposed method starts from the analysis of the current situation and the mapping of the company's ecosystem assets to answer these research questions: a) Is the company ready to create a PSS? b) How to select the right partners to realize the product-service VME? c) How to manage the PSS lifecycle?

The method steps are described below.

1. Analysis of the AS-IS Processes and Assets: It consists of two main activities; the first is related to the analysis of the current Product Lifecycle Management (PLM) process, from its ideation, through design, manufacturing and delivery, to disposal; the second consists of the mapping all the involved assets of the company and its ecosystem, both tangible (i.e. machines, materials, devices, sensors) and intangible (e.g. competences, skills, knowledge, relations among tangible components needed to realize another product functionality). The first analysis is supported by a modelling tool able to represent the company processes, identify all the activities involved in each process and, for each activity, the related input and output, the needed resources (e.g. human, material or IT), the involved competences and skills, and the control unit (e.g. company's departments, process's managers). The second mapping is supported by interviews and ad-hoc questionnaires, which investigate different aspects of the value creation process. In particular, each question is directly linked to a specific key business activity or resource identified in the company business model.

2. Analysis of the Servitization Readiness: It allows understanding if the company ecosystem is ready to create and manage a PSS solution or which areas should be improved. Such an analysis is based on the assessment of four areas 
(i.e. lifecycle management capability, ecosystem creation capability, innovation level, network management capability). Different questionnaires are defined to analyse the four areas.

3. Mapping of Tangible and Intangible Assets: It is based on the correlation between the new PSS items (i.e. product, services, ecosystem and infrastructure) and the related assets, mapping of the company ecosystem [21]. In fact, the PSS idea is defined by a set of tangible and intangible assets, coming from the specific competences and skills of the ecosystem partners. The mapping consists in tracing the network relations within the ecosystem, in terms of who has a certain knowledge, who provides a certain components, who realize a certain software application, who produces a specific product, who implements a specific service, etc.

4. Business Model Definition: It is based on the adoption of the Canvas model and allows clearly defining the company business model according to the previous results. It involves several areas within the company that should be defined in detail in order to identify which are the core areas where action is needed to implement the new business, such as key partners, key resources, key activities, value proposition, customer segments, channels, revenues streams, cost structure, and customer relationship. Business Model Canvas is used to analyse the building blocks of the new business model (service-centred), while STEEP analysis considers both internal and external factors related to environmental, political, economic, technological and social trends.

5. Definition of the TO-BE Integrated Product-Service Lifecycle and VME: It finally identifies the new lifecycle to properly manage both product-related and service-related activities and the actors involved. Starting from the previous ASIS processes modelling, it modifies the core factors individuated in points no. 2 and 3. Moreover, thanks to the definition of the new business model (point no. 4), the company can identify the partners and their own specific knowledge and skills that are necessary to realize the VME and develop the PSS desired.

After step no. 5, the company is ready to create, produce and manage the new product-service solution; in particular, it has defined a certain PSS and a precise VME to support its creation, delivery and operation. At this stage, the quality of the service implemented can be verified in different ways. This research focused on analysing the customer satisfaction and the sustainability index. Satisfaction can be analysed by satisfaction questionnaires and usability testing by directly involving final users, while sustainability is calculated by specific methods (i.e. LCA and LCC applied to the specific PSS solution) to compare the exist product with its related productservice to be developed.

\section{The Industrial Case Study in Household Appliances}

\subsection{The Company Ecosystem}

The case study has been realized in collaboration with an Italian company producing household appliances and home care devices. The company ecosystem is guided by 
the manufacturer and is actually organized in a vertical supply-chain adopting a product-oriented development process. Collaboration between the manufacturer and its partners and suppliers is limited to design stages and components' supply. The leader company recently designs and produces "smart appliances", defined as a manufactured product embedded with a hardware (e.g. sensors, Zigbee module, router Wi-Fi) and software (e.g. web service, data repository, web/mobile application) infrastructure to connect the product to an external network.

The case study focuses on services for smart appliances; in particular, it aims at realizing a new maintenance service, called "Smart Maintenance Service": it consists of providing ad-hoc maintenance services to the consumers for a set of smart appliances connected at home. The PSS involved in the case study consists of the appliances, a web/mobile application able to provide personalized messages for coaching purposes and helping the final users in case of appliances' faults. Figure 1 expresses the underpinning idea of the Smart Maintenance Service and shows the main workflow. Data related to the appliances functioning are monitored by specific sensors and are collected in a database for data storage; here, e set of elaboration algorithms analyse these data according to two policies (i.e. coaching and fault management) in order to recognize the specific use scenario and support the user with personalized and tailored suggestions and advices. For the coaching function, the application gives best practices according to the product usage; for the fault management function, the system controls the appliances' parameters, detects dangerous situations and supports the user when some critical values occur in order to carry out the recommended actions or some specific checking actions.

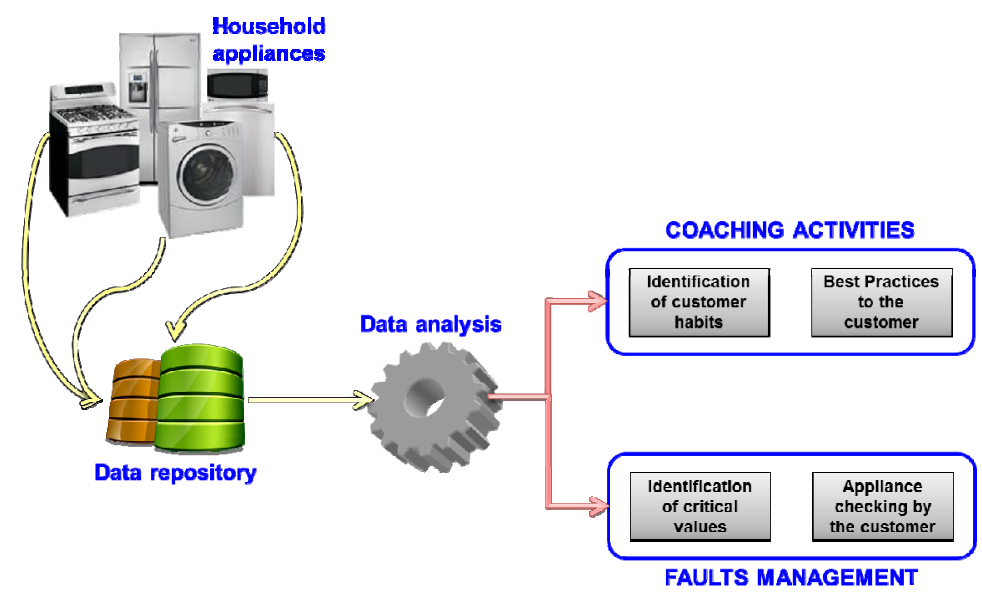

Fig. 1. The Smart Maintenance Service workflow

\subsection{AS-IS Process Analysis and Assets}

According to the methodology defined before, the company processes has been analysed. In particular, they refer to the following stages: "Product Conception", 
"Product Design", "Product Manufacturing”, "Product Delivery and Commercialization", and "Product Use". For each process stage, experts from both company and academia detailed the main activities and identified the departments involved, selected the key resources and modelled the activity flows. Moreover, interviews and questionnaires allows tracing the current assets and defining the product items in terms of functionalities, features, number of sensors, brand, production line, materials, any hardware supports (tangible assets) and intangible assets like partners involved in the ecosystem, brand resources, and customer relationships after sales.

\begin{tabular}{|c|c|c|c|c|c|c|c|}
\hline & $\begin{array}{c}\text { External } \\
\text { Information }\end{array}$ & $\begin{array}{l}\text { Customer } \\
\text { relationship }\end{array}$ & $\begin{array}{l}\text { PRODUCT } \\
\text { Conception }\end{array}$ & $\begin{array}{l}\text { PRODUCT } \\
\text { Design }\end{array}$ & $\begin{array}{c}\text { PRODUCT } \\
\text { Manufacturing }\end{array}$ & $\begin{array}{c}\text { PRODUCT } \\
\text { Delivery\&Comm. }\end{array}$ & $\begin{array}{c}\text { Internal } \\
\text { Information }\end{array}$ \\
\hline $\begin{array}{l}\text { STRATEGIC } \\
\text { level }\end{array}$ & $\begin{array}{l}\text { Existing appliances- } \\
\text { Image of the } \\
\text { company }\end{array}$ & $\begin{array}{l}\text { Customer } \\
\text { expectations }\end{array}$ & Business Plann & $\begin{array}{c}\text { Methodologies, } \\
\text { technical innovations, } \\
\text { and partners } \\
\text { selection }\end{array}$ & $\begin{array}{c}\text { Choice of } \\
\text { development } \\
\text { technologies }\end{array}$ & $\begin{array}{l}\text { Choice of the delivery } \\
\text { means - Define the } \\
\text { partner relationship }\end{array}$ & $\begin{array}{l}\text { Business strategy - } \\
\text { WM master } \\
\text { planning }\end{array}$ \\
\hline $\begin{array}{l}\text { TACTICAL } \\
\text { level }\end{array}$ & Existing technologies & $\begin{array}{l}\text { Medium term } \\
\text { feedback on } \\
\text { customer } \\
\text { satisfaction }\end{array}$ & $\begin{array}{l}\text { Benchmarking } \\
\text { activity; } \\
\text { brainstorming for } \\
\text { new ideas }\end{array}$ & $\begin{array}{l}\text { Definition of the new } \\
\text { product functions } \\
\text { and specifications }\end{array}$ & $\begin{array}{c}\text { Definition of } \\
\text { production process } \\
\text { and related action } \\
\text { plan }\end{array}$ & $\begin{array}{l}\text { General planning of } \\
\text { the product delivery }\end{array}$ & $\begin{array}{l}\text { Available } \\
\text { technologies }\end{array}$ \\
\hline $\begin{array}{l}\text { OPERATIONAL } \\
\text { level }\end{array}$ & Advertising & $\begin{array}{l}\text { Customers orders - } \\
\text { Customers claims }\end{array}$ & $\begin{array}{l}\text { Validation of } \\
\text { product orders }\end{array}$ & $\begin{array}{l}\text { Detailed design } \\
\text { planning }\end{array}$ & $\begin{array}{c}\text { Modification } \\
\text { implementation }\end{array}$ & $\begin{array}{l}\text { Short term delivery } \\
\text { planning - } \\
\text { Measurement of } \\
\text { performance }\end{array}$ & Status of production \\
\hline
\end{tabular}

Fig. 2. The product maintenance process analysis (AS-IS scenario)

\subsection{Analysis of the Servitization Readiness}

The analysis shows if the company is ready to implement the specific product-service solution and highlights the strengths and the possible weaknesses of the company in designing and managing the "Smart Maintenance Service" process. In the case study the analysis revealed that the company already has an ecosystem made up of different partners, suppliers, consortia and research centres and theoretically able to support product-service lifecycles, but such ecosystem is still strongly product-centred; services are perceived almost as tools to differentiate the product and do not represent the core business. The analysis also highlighted that the company is interested in understanding how to model and fully exploit PSS innovation projects. The case study defined also those areas (and related processes) to be improved to efficiently move to product-service solutions; they are: "Service Ideation", "Requirements analysis", and "Ecosystem governance and decision making".

\subsection{Mapping of the PSS Assets and Creation of the VME}

According to the PSS idea to develop (i.e. Smart Maintenance Service), a set of partners in the ecosystem are selected for their competences, skills, supplies, devices and knowledge, and their relationships are mapped in order to identify the better configuration of virtual manufacturing enterprise. The result of this study has given the following VME configuration: a research centre to support the PSS modelling, a technological partners to develop the IT infrastructure, a smart home provider able to 
share its competences about the household appliances connection into a network, a consortium for disposal, a consortium that studies innovative solutions, a partners to support the company during the delivery phase (e.g. during the best practices proposal) of the PSS, and the customers themselves.

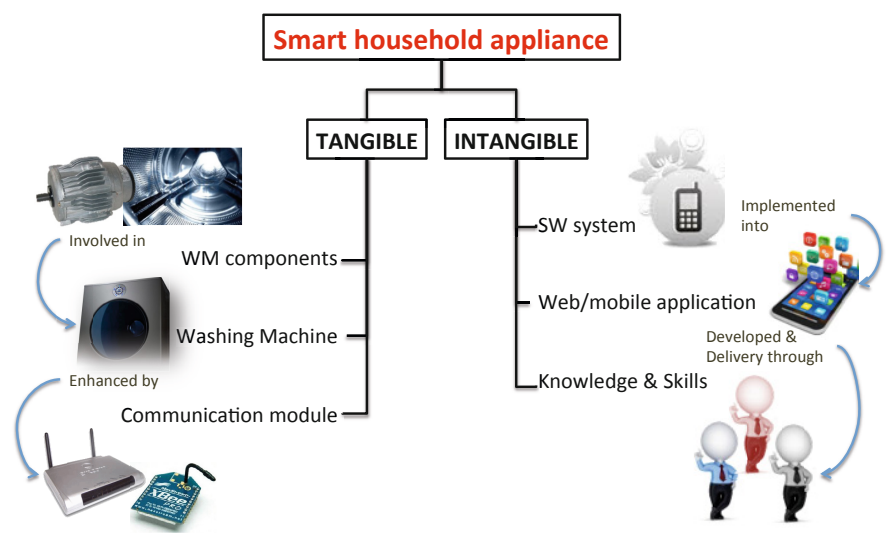

Fig. 3. Example of PSS assets mapping

\subsection{Business Model Definition}

A value proposition has been identified for the specific case study according to the Business Model Canvas. It consists of monitoring the household appliances and supports the maintenance process by web or mobile application and involving a group of selected partners (i.e. VME) performing the key activities to carry out preventive maintenance and coaching actions, PSS delivery and management. Figure 4 shows the identified business model: it addresses people that love smartness and convenience, and aims at creating making a long-term relationship between the customers and the company through on-line feedback, dynamic proposition and loyalty programs. Such a model can be delivered by local retailers as well as on-line shops, and can be implemented by different payment modes, from leasing contract to mobile payment.

\subsection{The Integrated Product-Service Lifecycle and TO-BE Processes}

Finally, an integrated product-service lifecycle has been defined to organize and manage all the information gathered in the previous steps. It starts from a recent model proposed in literature [22], that considers how the lifecycle phases are affected by changes due to transition from product to service (e.g. ideation, design, delivery). Figure 4 represents the global view of the TO-BE process by detailing the process activities, data input (e.g. target customer, partners in the ecosystem, competitors analysis), data output (e.g. from the PSS ideated to the creation of the Smart Maintenance), exploited resources (e.g. brainstorming activity, procedures, software infrastructure), and finally the involved competences and skills needed (e.g. coming from company departments, research centre, or technological partners). 


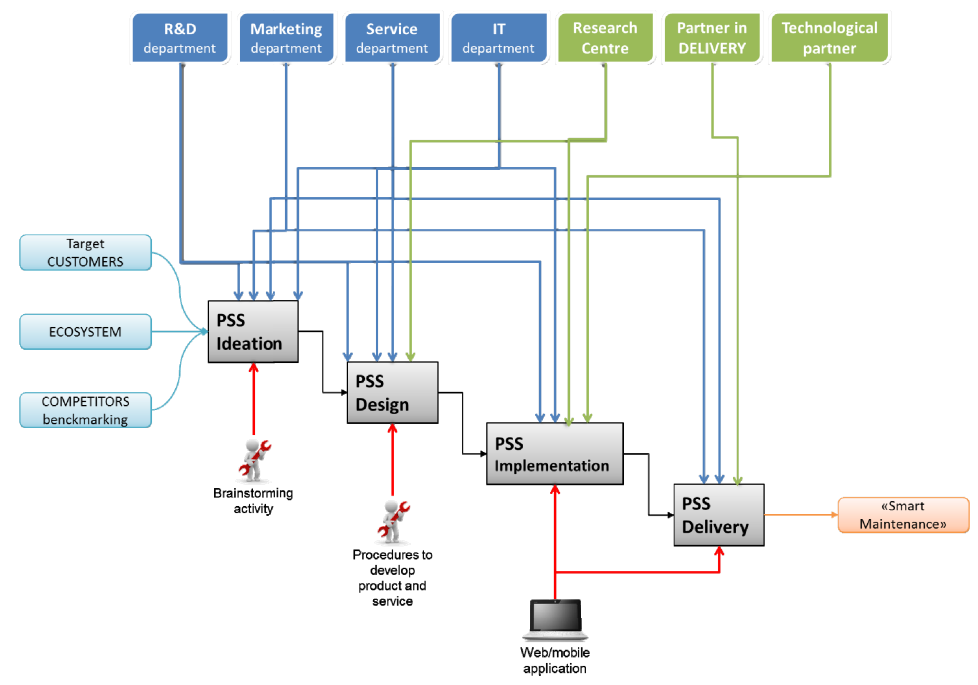

Fig. 4. Product-service lifecycle management process (TO-BE scenario)

\section{Conclusions}

The paper proposed a methodology to support manufacturing companies to achieve new product-service solutions by managing all the Product-Service lifecycle phases, from ideation to delivery. At the same time, the method allows analysing the company ecosystem in order to identify the virtual enterprise able to develop the specific PSS.

Such a methodology has been applied to an industrial case study focused on realizing services in the household appliances sector, the so-called Smart Maintenance Service. It demonstrated how the shift from a product-oriented to a service-oriented lifecycle can be properly managed and enhancing effective collaboration within the virtual enterprise. The results demonstrated how the Smart Maintenance Service is investigated and modelled, and what are the criticalities to face and solve to move for the AS-IS process until the TO-BE process.

\section{References}

1. Goedkoop, M.J., Van Halen, C.J.G., Riele, H.R.M., Rommens, P.J.M.: Product-Service Systems - Ecological and Economic Basic. PWC, The Hague (1999)

2. Thoben, K.D., Jagdev, H., Eschenbaecher, J.: Extended Products: Evolving Traditional Product Concepts. In: Proc. of 7th International Conference on Concurrent Enterprising (2001)

3. Baines, T.S., Lightfoot, H., Evans, S., Neely, A., Greenough, R., Peppard, J., Roy, R., Shehab, E., Braganza, A., Tiwari, A., Alcock, J.R., Angus, J.P., Bastl, M., Cousens, A., Irving, P., Johnson, M., Kingston, J., Lockett, H., Martinez, V., Michele, P., Tranfield, D., Walton, I.M., Wilson, H.: State of the art in Product-Service System. Journal of Engineering Manufacture 221, 1543-1552 (2007) 
4. Favi, C., Peruzzini, M., Germani, M.: A lifecycle design approach to analyse the ecosustainability of industrial products and product-service systems. In: Marjanovic, S., Pavkovic, B. (eds.) Proc. of International Design Conference DESIGN 2012, pp. 879-888 (2012)

5. Stahel, W.: The Utilization-Focused Service Economy, Resource Efficiency and ProductLife Extension. In: Allenby, B., Richard, D. (eds.) The Greening of Industrial Ecosystem, pp. 178-190. National Academy Press, Washington, DC (1994)

6. Camarinha-Matos, L.M.: Collaborative networked organizations: Status and trends in manufacturing. Annual Reviews in Control 33, 199-208 (2009)

7. Furrer, O.: Le rôle stratégique des services autour des produits. Revue Française de Gestion 113, 98-108 (2007)

8. SUSPRONET final report, http: / / www. suspronet.org/

9. Mont, O.K.: Clarifying the concept of Product-Service System. Journal of Cleaner Production 10(3), 237-245 (2002)

10. Aurich, J.C., Fuchs, C., Wagenknecht, C.: Life Cycle oriented design of technical ProductService Systems. Journal of Cleaner Production 14, 1480-1494 (2006)

11. Homburg, C., Garbe, B.: Towards an improved understanding of industrial services: quality dimensions and their impact on buyer-seller relationships. Journal of Business-toBusiness Marketing 6(2), 39-71 (1999)

12. Oliva, R., Kallenberg, R.: Managing the transition from products to services. International Journal of Service Industry Management 14(2), 160-172 (2003)

13. Baines, T.S., Lightfoot, H.W., Benedettini, O., Kay, J.M.: The servitization of manufacturing: A review of literature and reflection on future challenges. Journal of Manufacturing Technology Management 20(5), 547-567 (2009)

14. Tapscott, D., Williams, A.: Wikinomics: How Mass Collaboration Changes Everything. Penguin Books, New York (2006)

15. Windahl, C., Andersson, P., Berggren, C., Nehler, C.: Manufacturing firms and integrated solutions: characteristics and implications. European Journal of Innovation Management 7(3), 218-228 (2004)

16. Garetti, M., Rosa, P., Terzi, S.: Life Cycle Simulation for the design of Product-Service Systems. Computers in Industry 63, 361-369 (2012)

17. Peruzzini, M., Germani, M., Favi, C.: Shift from PLM to SLM: A method to support business requirements elicitation for service innovation. In: Rivest, L., Bouras, A., Louhichi, B. (eds.) PLM 2012. IFIP AICT, vol. 388, pp. 111-123. Springer, Heidelberg (2012)

18. Wiesner, S., Peruzzini, M., Doumeingts, G., Thoben, K.D.: Requirements Engineering for Servitization in Manufacturing Service Ecosystems (MSEE). In: Proc. 4th CIRP IPS2 Conference, Japan (2012)

19. Casadesus-Masanell, R.: Ricart, J.E.: From Strategy To Business Models And To Tactics. IESE Business School, University of Navarra, pp. 1-3 (2010)

20. Osterwalder, A., Pigneur, Y.: Business Model Generation. Modderman Druckwerk (2009)

21. Cassina, J., Cannata, A., Taisch, M.: Development of an Extended Product Lifecycle Management through Service Oriented Architecture (2009)

22. Peruzzini, M., Germani, M., Marilungo, E.: Product-service sustainability assessment in virtual manufacturing enterprises. In: Camarinha-Matos, L.M., Scherer, R.J. (eds.) PRO-VE 2013. IFIP AICT, vol. 408, pp. 13-21. Springer, Heidelberg (2013) 